\title{
PENGARUH PROGRAM DIALOG INTERAKTIF "HALO KALTIM" RADIO REPUBLIK INDONESIA TERHADAP TINGKAT KEPUASAN PENDENGAR
}

\author{
Oleh : \\ Heriyanto $^{1}$, Eddy Soegiarto ${ }^{2}$ dan Selviana Meikayanti ${ }^{3}$ \\ ${ }^{1}$ dan ${ }^{2}$ Fakultas Ekonomi Universitas 17 Agustus 1945 Samarinda \\ ${ }^{3}$ Fakultas Ekonomi Universitas 17 Agustus 1945 Samarinda
}

\begin{abstract}
The growth of the mass media industry in recent years has shown increasingly tight competencies. At first there were only electronic media and print media such as radio, television and newspapers. But now there are online media via the Internet such as websites or web. The development of online media users in Indonesia makes print media, such as radio, should present the best breakthrough for the target audience, to survive in the future.

This research is intended to examine the effect of the program quality "Halo Kaltim" to the listener's satisfaction at Radio Republik Indonesia Samarinda. The research was conducted using regression analysis techniques on 88 listeners of the Interactive Dialogue Program "Halo Kaltim".

The results showed that program quality had a positive and significant effect on listener satisfaction. This shows that improve the program quality "Halo Kaltim" will increase the listener's satisfaction of the program "Halo Kaltim" Radio Republik Indonesia Samarinda.

Radio Republik Indonesia Samarinda is expected to maintain the interactive dialogue program quality "Halo Kaltim" because it has a significant effect on listeners' satisfaction Interactive Dialogue Radio Program "Halo Kaltim" Radio Republik Indonesia Samarinda.
\end{abstract}

Keyword : Radio Program Quality, Listener Satisfaction 


\section{PENDAHULUAN}

\section{A. Latar Belakang}

Pertumbuhan industri media masa dalam tahun-tahun terakhir ini semakin menunjukkan kompetensi yang ketat. Situasi ini disebabkan karena pertumbuhan media masa yang cepat dari tahun ke tahun, sangat beragam jenisnya dan mulai tersegmentasi dengan jelas. Pada awalnya hanya ada media eletronik dan media cetak seperti radio televisi dan juga surat kabar. Namun saat ini sudah ada media online lewat internet seperti situs atau web. Semakin berkembangnya pengguna media online atau internet di Indonesia menjadikan media masa cetak dan eletronik selalu berlomba untuk menyajikan terobosan yang terbaik bagi khalayak sasarannya (pembaca, pendengar, dan pemirsa).

Radio sebagai media masa auditif, yakni media yang mengandalkan pendengaran juga diharapkan untuk mampu bertahan ditengah persaingan industri media masa dalam tahun-tahun terakhir ini yang semakin menunjukkan kompetensi yang ketat. Menurut Riswandi (2009: 1), penyiaran radio adalah media komunikasi masa dengan yang menyalurkan gagasan informasi dalam bentuk suara secara umum dan terbuka, berupa program yang teratur dan berkesinambungan. Radio berasal dari kata Radios yang berarti benda-benda elektronika yang menciptakan suara untuk berkomunikasi. Radio merupakan alat menyampaikan informasi dengan memanfaatkan adanya gelombang elektromagnetik.

Di Indonesia, Radio pertama yang mengudara yaitu RRI (Radio Republik Indonesia) yang dikelola oleh pemerintah baru setelah itu disusul oleh radio-radio swasta niaga. RRI Samarinda adalah salah satu cabang stasiun radio milik Radio Republik Indonesia. Yang mengcover seluruh siaran di wilayah Kalimantan timur. Beralamat di Jalan M. Yamin No.8 Samarinda Kalimantan Timur, RRI Samarinda secara historis lahir pada tanggal 20 mei 1954 memiliki catatan dan nilai sejarah tersendiri di antara 53 stasiun penyiaran RRI yang ada sekarang di Indonesia. Kehadiranya mampu meraih hati masyarakat kota samarinda dan sekitarnya melalui misi hiburan, informasi dan pendidikan.

Salah satu program aktif di RRI PRO 1 Samarinda adalah Program Dialog Interaktif Halo Kaltim. Merupakan program utama di RRI PRO 1 Samarinda yang mengudara setiap hari dalam durasi 1 sampai dengan 2 jam sehari. Program Dialog Interaktif Halo Kaltim merupakan agenda diskusi yang membahas sebuah topik yang sedang hangat dibicarakan oleh masyarakat Kaltim, yang dilakukan dengan mengundang orang yang ahli (pakar) dalam topik tersebut sebagai narasumber. 


\section{B. Rumusan Masalah}

Berdasarkan latar belakang yang telah dipaparkan sebelumnya diketahui bahwa pada tahun 2019 jumlah pendengar Program Dialog Interaktif Halo Kaltim yang secara aktif berkomunikasi melalui media Short Message Service (SMS) saat program sedang berlangsung mengalami fluktuasi setiap bulannya. Sehingga penelitian ini ingin menguji kembali apakah kualitas program berpengaruh signifikan terhadap kepuasan pendengar Program Radio Dialog Interaktif Halo Kaltim Radio Republik Indonesia Samarinda.

\section{Tujuan Penelitian}

Tujuan dari penelitian ini adalah untuk mengetahui pengaruh kualitas Program Radio Dialog Interaktif Halo Kaltim Radio Republik Indonesia terhadap kepuasan pendengar Program Radio Dialog Interaktif Halo Kaltim Radio Republik Indonesia Samarinda.

\section{KERANGKA DASAR TEORI}

\section{A. Manajemen Pemasaran}

Manusia sebagai konsumen membeli barang dan jasa adalah untuk memuaskan keinginan dan kebutuhan hidup. Hal ini berarti konsumen tidak hanya membeli produk atau barangnya saja, akan tetapi yang dibeli adalah manfaat atau kegunaan dari produk tersebut. Dalam berbisnis ada banyak hal yang harus diperhatikan antara lain adalah Manajemen Pemasaran. Manajemen pemasaran adalah suatu kegiatan yang penting bagi sebuah bisnis. Tanpa adanya manajemen yang baik, pemasaran tidak bisa berjalan dengan semestinya. Padahal, pemasaran adalah kegiatan yang penting untuk menggaet banyak konsumen dan mendatangkan banyak keuntungan bagi perusahaan.

Sedangkan menurut Kotler dan Keller (2012: 28) : Yang berarti manajemen pemasaran merupakan seni dan ilmu memilih pasar sasaran dan meraih, mempertahankan serta menumbuhkan pelanggan dengan menciptakan, menghantarkan dan mengomunikasikan nilai pelanggan yang umum.

Dari definisi menurut ahli tersebut dapat disimpulkan bahwa manajemen pemasaran adalah seni dan ilmu dalam melakukan aktivitas perencanaan, penetapan harga dan pendistribusian produk kepada pasar sasaran untuk mencapai kepuasan pelanggan yang merupakan tujuan dari organisasi. Pemasaran sangat berperan penting terhadap kelangsungan bisnis, seperti menentukan target pasar yang tepat, menentukan harga produk yang sesuai dan dapat dijangkau oleh target pasar hingga menentukan cara mengemas produk atau jasa agar lebih mudah diterima oleh masyarakat. 


\section{B. Jasa}

\section{Pengertian Jasa}

Menurut Kotler dan Keller (2012: 378), "A service is any act or performance that one party can offer to another that is essentially intangible and does not result in the ownership of anything. It may or may not be tied to a physical product". Yang bermakna jasa adalah setiap tindakan atau kinerja yang dapat ditawarkan kepada pihak lain, pada dasarnya tidak berwujud dan tidak mengakibatkan kepemilikian apa pun, produksi jasa mungkin berkaitan dengan produk fisik atau tidak.

\section{Pemasaran Jasa}

Pemasaran jasa merupakan disiplin ilmu yang masih relatif baru. Industri jasa pada saat ini merupakan sektor ekonomi yang sangat besar dan tumbuh sangat pesat. Pertumbuhan tersebut akibat dari tuntuan dan perkembangan teknologi. Kondisi tersebut secara langsung menghadapkan para pelaku bisnis kepada permasalahan persaingan usaha yang semakin tinggi, semakin tingginya tingkat persaingan sehingga diperlukan manajemen pemasaran jasa yang berbeda dibandingkan dengan pemasaran tradisional (barang).

Menurut Kotler dan Keller (2012: 5), "Marketing is meeting needs profitably", maksud ungkapan tersebut adalah pemasaran merupakan hal yang dilakukan untuk memenuhi setiap kebutuhan (kebutuhan pelanggan) dengan cara-cara yang menguntungkan semua pihak.

\section{HASIL PENELITIAN}

\section{A. Gambaran Umum Objek Penelitian}

RRI adalah satu-satunya radio yang menyandang nama negara yang siarannya ditujukan untuk kepentingan bangsa dan negara. RRI sebagai Lembaga Penyiaran Publik yang independen, netral dan tidak komersial yang berfungsi memberikan pelayanan siaran informasi, pendidikan, hiburan yang sehat, kontrol sosial, serta menjaga citra positif bangsa di dunia internasional. Besarnya tugas dan fungsi RRI yang diberikan oleh negara melalui UU no 32 tahun 2002 tentang Penyiaran, PP 11 tahun 2005 tentang Lembaga Penyiaran Publik, serta PP 12 tahun 2005, RRI dikukuhkan sebagai satu-satunya lembaga penyiaran yang dapat berjaringan secara nasional dan dapat bekerja sama dalam siaran dengan lembaga penyiaran Asing. Dengan kekuatan 99 stasiun penyiaran terdiri dari: 1 satker tipe A, 30 satker tipe B, 34 satker tipe C, Pusat Pemberitaan dan SLN serta 32 Studio Produksi. Adapun prinsip-prinsip Lembaga Penyiaran Publik diantaranya:

1) LPP adalah lembaga penyiaran untuk semua warga Negara

2) Siarannya harus menjangkau seluruh wilayah Negara

3) Siarannya harus merefleksikan keberagaman 
4) Siarannya harus berbeda dengan lembaga penyiaran lainnya

5) LPP harus menegakkan independensi dan netralitas

6) Siarannya harus bervariasi dan berkualitas tinggi

7) Menjadi flag carrier dari bangsa indonesia

8) Mencerminkan identitas bangsa

9) Perekat dan pemersatu bangsa

\section{Deskripsi Data}

Penelitian dilakukan terhadap terhadap 88 orang responden yang merupakan pendengar Program Radio Dialog Interaktif Halo Kaltim Radio Republik Indonesia Samarinda dengan karakteristik sebagai berikut.

Tabel 1

Karakteristik Responden

\begin{tabular}{|l|c|r|}
\hline \multicolumn{1}{|c|}{ Jenis Kelamin } & Jumlah & Persentase \\
\hline Laki-Laki & 61 & $69,30 \%$ \\
\hline Perempuan & 27 & $30.70 \%$ \\
\hline Total & 88 & $100,00 \%$ \\
\hline \multicolumn{1}{|c|}{ Usia } & Jumlah & Persentase \\
\hline$<25$ Tahun & 16 & $18,20 \%$ \\
\hline $25-35$ Tahun & 58 & $65,90 \%$ \\
\hline$>35$ Tahun & 14 & $15,90 \%$ \\
\hline Total & 88 & $100,00 \%$ \\
\hline \multicolumn{1}{|c|}{ Domisili } & Jumlah & Persentase \\
\hline Balikpapan & 18 & $20,50 \%$ \\
\hline Berau & 2 & $2,30 \%$ \\
\hline Bontang & 2 & $2,30 \%$ \\
\hline Kota Bangun & 1 & $1,10 \%$ \\
\hline Muara Badak & 1 & $1,10 \%$ \\
\hline Paser & 3 & $3,40 \%$ \\
\hline Samarinda & 49 & $55,70 \%$ \\
\hline Samboja & 2 & $2,30 \%$ \\
\hline Sanga-Sanga & 2 & $2,30 \%$ \\
\hline Sangatta & 1 & $1,10 \%$ \\
\hline Sangkulirang & 1 & $1,10 \%$ \\
\hline Tenggarong & 6 & $6,80 \%$ \\
\hline Total & 88 & $100,00 \%$ \\
\hline
\end{tabular}

Sumber: Data Diolah (2020) 
Berdasarkan tabel karakteristik responden diatas, diketahui bahwa responden didominasi pendengar dengan jenis kelamin laki-laki sebanyak 61 orang atau $69,30 \%$ dari total responden penelitian. Sedangkan responden yang perempuan hanya sebanyak 27 orang atau $30,70 \%$ dari total responden penelitian.

Berdasarkan karakteristik usianya, diketahui bahwa reponden didominasi pendengar berusia 25-35 tahun sebanyak 58 orang atau $65,90 \%$ dari total responden penelitian. Menyusul setelahnya responden yang berusia kurang dari 25 tahun sebanyak 16 orang atau $18,20 \%$ dari total responden penelitian. Sedangkan responden yang berusia lebih dari 35 tahun sebanyak 14 orang atau 15,90\% dari total responden penelitian.

Berdasarkan karakteristik daerah domisilinya, diketahui bahwa reponden didominasi pendengar yang berdomisili di Samarinda sebanyak 49 orang atau $55,70 \%$ dari total responden penelitian. Menyusul setelahnya responden yang berdomisili di Balikpapan sebanyak 18 orang atau $20,50 \%$ dari total responden penelitian. Sedangkan responden lain berdomisili di beberapa daerah lain, yaitu: Berau, Bontang, Kota Bangun, Muara Badak, Paser, Samboja, SangaSanga, Sangatta, Sangkulirang, dan Tenggarong.

\section{PEMBAHASAN}

\section{A. Uji Validitas}

Uji validitas dimaksudkan untuk melihat apakah suatu instrumen mampu mengukur apa yang seharusnya diukur serta mengungkapkan data dari variabel yang diteliti secara tepat. Pengujian validitas suatu butir pernyataan dilakukan dengan cara membandingkan angka koefisien korelasi butir $\left(r_{\text {hitung }}\right)$ dengan angka korelasi tabel $\left(r_{\text {tabel }}\right)$. Jika nilai $r_{\text {hitung }}>r_{\text {tabel }}$, maka butir pernyataan dinyatakan valid dan layak digunakan untuk mengukur variabel yang seharusnya diukur. Pengujian dilakukan pada taraf signifikansi 5\% (two tailed) dengan df 86 (88-2) dan $\mathrm{r}_{\text {tabel }} 0,2096$.

\section{Tabel 2}

Hasil Uji Validitas Instrumen Kualitas Program (X)

\begin{tabular}{|l|c|c|c|}
\hline \multicolumn{1}{|c|}{ Pernyataan } & $\mathbf{r}_{\text {hitung }}$ & $\mathbf{r}_{\text {tabel }}$ & Keterangan \\
\hline Kualitas Program 1 & 0,727 & 0,2096 & Valid \\
\hline Kualitas Program 2 & 0,771 & 0,2096 & Valid \\
\hline Kualitas Program 3 & 0,745 & 0,2096 & Valid \\
\hline Kualitas Program 4 & 0,730 & 0,2096 & Valid \\
\hline Kualitas Program 5 & 0,488 & 0,2096 & Valid \\
\hline
\end{tabular}

Sumber: Data Diolah (2020) 
Hasil pengujian validitas untuk masing-masing pernyataan yang digunakan mengukur variabel Kualitas Program menunjukkan nilai $r_{\text {hitung }}>$ $r_{\text {tabel}}$, sehingga pernyataan-pernyataan tersebut dikatakan valid untuk mengukur variabel Kualitas Program.

\section{Tabel 3}

Hasil Uji Validitas Instrumen Kepuasan Pendengar (Y)

\begin{tabular}{|c|c|c|c|}
\hline Pernyataan & $\mathbf{r}_{\text {hitung }}$ & $\mathbf{r}_{\text {tabel }}$ & Keterangan \\
\hline Kepuasan Pendengar 1 & 0,809 & 0,2096 & Valid \\
\hline Kepuasan Pendengar 2 & 0,841 & 0,2096 & Valid \\
\hline Kepuasan Pendengar 3 & 0,879 & 0,2096 & Valid \\
\hline
\end{tabular}

Sumber: Data Diolah (2020)

Hasil pengujian validitas untuk masing-masing pernyataan yang digunakan mengukur variabel Kepuasan Pendengar menunjukkan nilai $\mathrm{r}_{\text {hitung }}$ $>r_{\text {tabel}}$, sehingga pernyataan-pernyataan tersebut dikatakan valid untuk mengukur variabel Kepuasan Pendengar.

\section{B. Uji Reliabilitas}

Uji reliabilitas dimaksudkan untuk melihat sejauh mana suatu hasil pengukuran relatif konsisten apabila pengukuran diulangi dua kali atau lebih. Suatu alat ukur disebut mempunyai reliabitas tinggi atau dapat dipercaya jika alat ukur itu mantap dalam pengertian bahwa alat ukur tersebut stabil dapat diandalkan dan dapat diramaikan. Jika reliabilitas Cronbach Alpha melebihi angka 0,6 maka item pernyataan variabel tersebut dikatakan handal atau reliabel.

\section{Tabel 4}

Hasil Uji Reliabilitas

\begin{tabular}{|l|c|c|}
\hline \multicolumn{1}{|c|}{ Variabel } & Cronbach Alpha & Keterangan \\
\hline Kualitas Program & 0,731 & Reliabel \\
\hline Kepuasan Pendengar & 0,795 & Reliabel \\
\hline
\end{tabular}

Sumber: Data Diolah (2020)

Berdasarkan hasil analisis diatas dapat disimpulkan bahwa seluruh pernyataan yang berkaitan dengan variabel Kualitas Program dan variabel Kepuasan Pendengar dikatakan reliabel. Hal ini dapat dilihat dari nilai Cronbach Alpha yang $\geq 0,60$, berturut-turut 0,731 dan 0,795. Sehingga seluruh pernyataan pada penelitian ini memiliki tingkat kehandalan yang baik dan dapat digunakan sebagai instrumen dalam penelitian ini. 


\section{Uji Asumsi Klasik}

1. Uji Normalitas

Uji normalitas dimaksudkan untuk menguji apakah dalam model regresi, variabel pengganggu atau residual terdistribusi normal. Untuk uji normalitas, penelitian ini menggunakan uji Kolmogorov-Smirnov. Kriteria yang digunakan adalah jika tingkat signifikansi hasil perhitungan data $>$ $5 \%$, maka residual pada model regresi berdistribusi normal, sedangkan jika tingkat signifikansi hasil perhitungan data $<5 \%$ maka residual pada model regresi tidak berdistribusi normal.

\section{Tabel 5}

\section{Hasil Uji Normalitas}

One-Sample Kolmogorov-Smirnov Test

\begin{tabular}{|ll|r|}
\hline & & $\begin{array}{r}\text { Unstandardiz } \\
\text { ed Residual }\end{array}$ \\
\hline $\mathrm{N}$ & & 88 \\
Normal Parameters & Mean & .0000000 \\
& Std. & 1.29601190 \\
Most Extreme & Deviation & .084 \\
Differences & Absolute & .063 \\
& Positive & -.084 \\
Test Statistic & Negative & .084 \\
Asymp. Sig. (2-tailed) & & $.171^{\mathrm{c}}$ \\
\hline
\end{tabular}

a. Test distribution is Normal.

b. Calculated from data.

c. Lilliefors Significance Correction.

Hasil uji normalitas menunjukkan nilai Asymp. Sig. sebesar 0,171 (lebih besar dari 0,05), sehingga dapat disimpulkan residual pada model regresi berdistribusi normal.

\section{Uji Heteroskedastisitas}

Uji heteroskedastisitas bertujuan untuk menguji apakah dalam model regresi terjadi ketidaksamaan varians dari residual satu pengamatan ke pengamatan lain, jika varians dari residual satu pengamatan ke pengamatan lain berbeda maka disebut heteroskedastisitas. Jika ada pola tertentu, seperti titik yang ada membentuk pola tertentu teratur (bergelombang, melebur kemudian menyempit), maka mengindikasikan telah terjadi heteroskedatisitas. 


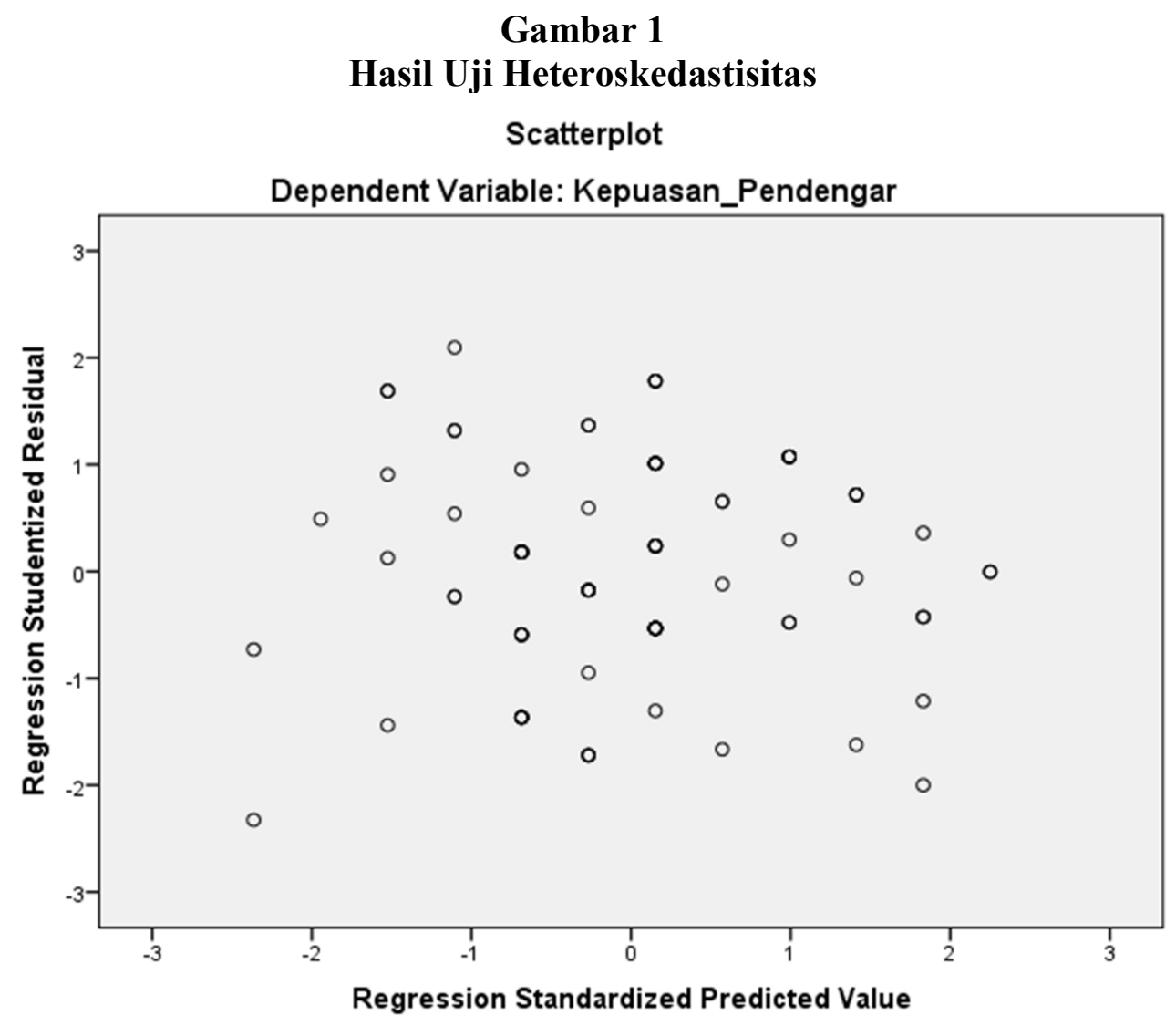

Hasil uji heteroskedastisitas melalui grafik diatas tidak menunjukkan pola tertentu, seperti titik yang ada membentuk pola tertentu teratur (bergelombang, melebur kemudian menyempit), sehingga dapat disimpulkan tidak terdapat gejala heteroskedastisitas pada model regresi.

\section{Uji Linieritas}

Uji linearitas dimaksudkan untuk mengetahui apakah dua variabel mempunyai hubungan yang linear atau tidak secara signifikan. Pengujian dilakukan menggunakan Test for linearity dengan taraf signifikan 0,05. Dua variabel dikatakan mempunyai hubungan yang linear bila tingkat signifikan kurang dari 0,05. 


\section{Tabel 6}

Hasil Uji Linieritas

ANOVA Table

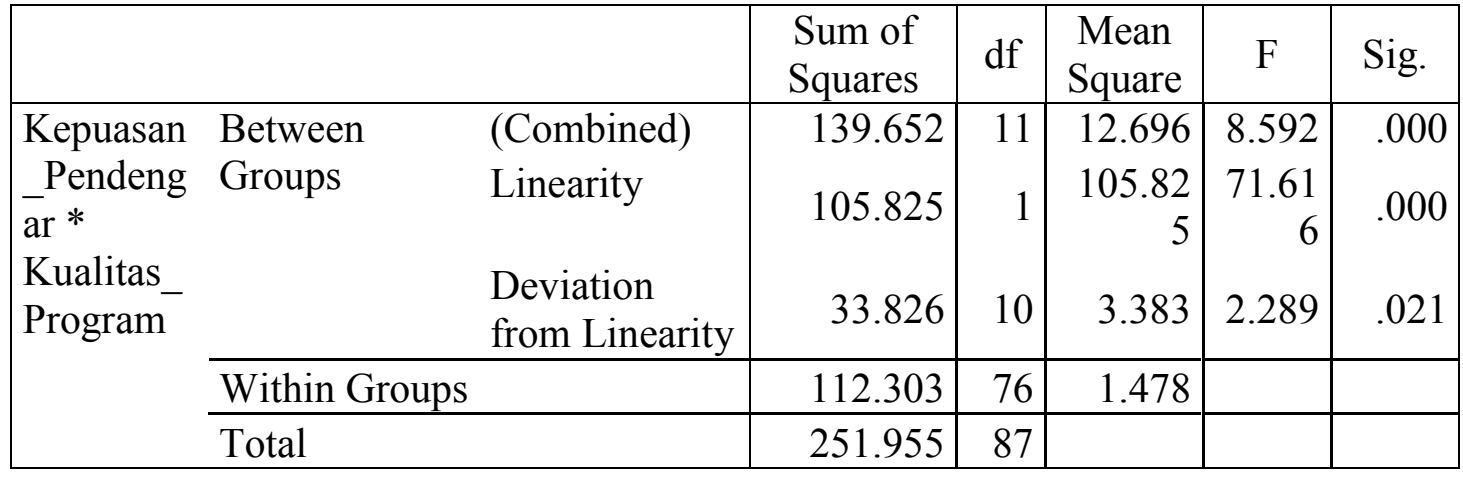

Hasil uji linieritas menunjukkan nilai Liniearity kurang dari 0,05 $(0,000)$, sehingga dapat disimpulkan bahwa hubungan antara variabel Kualitas Program dan variabel Kepuasan Pendengar membentuk hubungan yang linier.

\section{Uji Kelayakan Model}

\section{a. Uji Koefisien Korelasi dan Koefisien Determinasi}

Pengujian koefisien korelasi dimaksudkan untuk menunjukkan kuat atau lemahnya hubungan antara variabel indepeden (X) dengan variabel dependen (Y). Selain itu, dapat pula untuk menentukan arah hubungan antara kedua variabel apakah mempunyai arah hubungan positif atau negatif. Apabila nilai koefisien korelasi semakin mendekati 1 atau -1, maka hubungan antara kedua variabel semakin erat. Sedangkan koefisien determinasi adalah sebuah bilangan yang menyebutkan proporsi variasi perubahan nilai-nilai $\mathrm{Y}$ yang ditentukan oleh variasi perubahan nilai-nilai $X$.

\section{Tabel 7}

Hasil Uji Koefisien Korelasi dan Koefisien Determinasi Model Summary ${ }^{\text {b }}$

\begin{tabular}{|l|r|r|r|r|}
\hline Model & \multicolumn{1}{|c|}{$\mathrm{R}$} & R Square & $\begin{array}{c}\text { Adjusted R } \\
\text { Square }\end{array}$ & $\begin{array}{c}\text { Std. Error of } \\
\text { the Estimate }\end{array}$ \\
\hline 1 & $.648^{\mathrm{a}}$ & .420 & .413 & 1.30353 \\
\hline
\end{tabular}

a. Predictors: (Constant), Kualitas_Program

b. Dependent Variable: Kepuasan_Pendengar

Berdasarkan hasil analisis diketahui bahwa nilai $\mathrm{R}$ (korelasi) sebesar 0,648 , berada pada rentang korelasi $0,50-0,75$, sehingga dapat disimpulkan bahwa antara Kualitas Program dengan Kepuasan 
Pendengar memiliki tingkat hubungan yang kuat. Sedangkan nilai $\mathrm{R}$ Square yang menunjukkan besarnya kemampuan variabel bebas dalam menjelaskan variabel terikat diketahui sebesar 0,420 atau 42,00\%, yang bermakna bahwa Kepuasan Pendengar mampu dijelaskan oleh Kualitas Program sebesar $42,00 \%$, sedangkan sisanya 58,00\% dijelaskan oleh variabel lain diluar model penelitian.

b. Uji F

Uji F atau Goodness of Fit Test adalah pengujian kelayakan model regresi yang terbentuk. Model yang layak adalah model yang dapat digunakan untuk mengestimasi populasi. Model regresi dikatakan layak jika nilai $\mathrm{F}$ sebuah model memenuhi kriteria yang telah ditetapkan. Jika nilai signifikansi kurang dari 0,05 , maka model regresi dinyatakan layak dan dapat digunakan untuk mengestimasi populasi.

\section{Tabel 8}

\section{Hasil Uji F}

ANOVA ${ }^{\mathrm{a}}$

\begin{tabular}{|rl|r|r|r|r|c|}
\hline \multicolumn{1}{|c|}{ Model } & \multicolumn{1}{c|}{$\begin{array}{c}\text { Sum of } \\
\text { Squares }\end{array}$} & df & Mean Square & F & Sig. \\
\hline 1 & Regression & 105.825 & 1 & 105.825 & 62.280 & $.000^{\mathrm{b}}$ \\
& Residual & 146.129 & 86 & 1.699 & & \\
& Total & 251.955 & 87 & & & \\
\hline
\end{tabular}

a. Dependent Variable: Kepuasan_Pendengar

b. Predictors: (Constant), Kualitas_Program

Berdasarkan hasil pengujian diketahui bahwa nilai signifikansi kurang dari $0,05(0,000)$, sehingga dapat disimpulkan bahwa model regresi yang terbentuk untuk menjelaskan hubungan Kualitas Program Dialog Interaktif Halo Kaltim Radio Republik Indonesia Samarinda dan Kepuasan Pendengar Program Dialog Interaktif Halo Kaltim Radio Republik Indonesia Samarinda dinyatakan layak.

Tabel 5.

Hasil Uji t

Coefficients $^{\mathrm{a}}$

\begin{tabular}{|rl|r|r|r|r|r|}
\hline \multirow{2}{*}{ Model } & \multicolumn{2}{|c|}{$\begin{array}{c}\text { Unstandardized } \\
\text { Coefficients }\end{array}$} & $\begin{array}{l}\text { Standardized } \\
\text { Coefficients }\end{array}$ & \multirow{2}{*}{$\mathrm{t}$} & \multirow{2}{*}{ Sig. } \\
\cline { 2 - 5 } & \multicolumn{1}{|c|}{ B } & Std. Error & \multicolumn{1}{c|}{ Beta } & & \\
\hline 1 & 3.438 & 1.160 & & 2.965 & .004 \\
& $\begin{array}{l}\text { (Constant) } \\
\text { Kualitas_Progra } \\
\text { m }\end{array}$ & .463 & .059 & .648 & 7.892 & .000 \\
\hline
\end{tabular}

a. Dependent Variable: Kepuasan_Pendengar 
Hasil pengujian pada Tabel 5 diatas selanjutnya dapat disusun ke dalam model struktur persamaan pada regresi linear sederhana sebagai berikut:

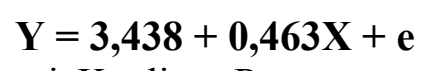

Koefisien regresi Kualitas Program sebesar 0,463 dengan nilai positif. Koefisien regresi bernilai positif yang artinya terjadi hubungan positif antara Kualitas Program dengan Kepuasan Pendengar, dimana semakin meningkat Kualitas Program maka akan semakin meningkat pula Kepuasan Pendengar, yang bermakna jika Kualitas Program mengalami kenaikan sebesar 1 satuan, maka Kepuasan Pendengar akan mengalami kenaikan sebesar 0,463. Pengaruh Kualitas Program terhadap Kepuasan Pendengar memiliki nilai signifikansi sebesar 0,000 $(<0,05)$, sehingga hipotesis yang menyatakan "Kualitas Program Dialog Interaktif Halo Kaltim berpengaruh signifikan terhadap Kepuasan Pendengar Dialog Interaktif Halo Kaltim" diterima.

Berdasarkan hasil pengujian hipotesis, diketahui bahwa Kualitas Program berpengaruh positif dan signifikan terhadap Kepuasan Pendengar. Dengan demikian, hipotesis dalam penelitian yang menyatakan bahwa Kualitas Program Dialog Interaktif Halo Kaltim berpengaruh signifikan terhadap Kepuasan Pendengar Dialog Interaktif Halo Kaltim, diterima. Hal ini menunjukan bahwa peningkatan Kualitas Program Dialog Interaktif Halo Kaltim Radio Republik Indonesia Samarinda akan meningkatkan Kepuasan Pendengar Program Dialog Interaktif Halo Kaltim Radio Republik Indonesia Samarinda.

Kualitas program adalah bentuk pengukuran terhadap nilai layanan yang telah diterima oleh pendengar dari Program Dialog Interaktif Hallo Kaltim Radio Republik Indonesia Samarinda dalam memenuhi kebutuhan dan keinginan harapan pelanggan. Kualitas memberikan suatu dorongan kepada pelanggan untuk menjalin ikatan hubungan yang kuat dengan perusahaan. Dalam jangka panjang, ikatan seperti ini memungkinkan perusahaan untuk memahami dengan seksama harapan pelanggan serta kebutuhan mereka sehingga perusahaan dapat meningkatkan kepuasan pelanggan dengan cara memaksimalkan pengalaman pelanggan yang menyenangkan dan meminimalkan atau meniadakan pengalaman pelanggan yang kurang menyenangkan.

Sedangkan Kepuasan adalah perasaan senang atau kecewa yang muncul setelah membandingkan kinerja (hasil) produk maupun jasa yang dipikirkan terhadap kinerja atau hasil yang diharapkan. Sehingga kepuasan pendengar adalah suatu penilaian emosional dari para pendengar setelah mendengarkan Program Dialog Interaktif Hallo Kaltim Radio Republik Indonesia Samarinda, dimana harapan dan kebutuhan pendengar telah terpenuhi. Dalam hal ini kepuasan pendengar 
sangat bergantung pada kualitas Program Dialog Interaktif Hallo Kaltim Radio Republik Indonesia Samarinda yang diberikan.

Hasil penelitian menunjukkan bahwa pendengar menganggap Program Dialog Interaktif Halo Kaltim sebagai program yang berkualitas yang disajikan Radio Republik Indonesia Samarinda.

Program tersebut dianggap mampu memberikan penambahan informasi, pengetahuan dan pemahaman mengenai lingkungan sekitar sehingga membuat pendengar merasa tujuannya untuk mendengarkan radio terpenuhi. Informasi menjadi sangat penting sekali dan sangat dibutuhkan pendengar dalam menambah wawasan dan pengetahuan, terutama informasi-informasi yang berkaitan dengan kejadian-kejadian atau masalah-masalah yang muncul di lingkungan sekitar pendengar. Selain itu Program Dialog Interaktif Halo Kaltim merupakan Lembaga Penyiaran Publik yang resmi dari Pemerintah sehingga informasi yang disajikan dianggap memiliki tingkat kepercayaan dan keakuratan yang lebih baik dibandingkan informasi yang beredar diluar.

Program Dialog Interaktif Halo Kaltim juga mampu memberikan pengalaman yang menyenangkan dan emosional kepada pendengar melalui beberapa materi yang mungkin bersinggungan langsung dengan kehidupan pendengar atau masalah yang sedang dihadapi pendengar sehingga materi yang didengarkan menjadi lebih menarik karena melibatkan langsung perasaan pendengar.

Pendengar juga menganggap bahwa selama ini Program Dialog Interaktif Halo Kaltim mampu menambah kepercayaan diri pendengar, membuat pendengar memperoleh lebih banyak teman untuk bersosialisasi, dan terkadang mampu menghindarkan tekanan dan ketegangan yang pendengar alami setelah seharian beraktivitas. Program Dialog Interaktif Halo Kaltim mampu memberikan informasi-informasi penting yang dapat menambah wawasan pendengar sehingga membantu mereka lebih percaya diri dalam berkomunikasi dengan orang lain. Selain itu pendengar dapat memanfaatkan sesi tanya jawab melalui SMS yang disediakan Dialog Interaktif Halo Kaltim untuk memperkenalkan diri dan menambah lingkungan pertemanan.

Hal tersebut kemudian berperan dalam mendorong pendengar untuk mendengarkan Program Dialog Interaktif Halo Kaltim kembali dan bahkan merekomendasikan orang lain untuk juga mendengarkan Program Dialog Interaktif Halo Kaltim. 


\section{PENUTUP}

Kualitas Program berpengaruh positif dan signifikan terhadap Kepuasan Pendengar. Hal ini menunjukan bahwa peningkatan Kualitas Program Dialog Interaktif Halo Kaltim Radio Republik Indonesia Samarinda akan meningkatkan Kepuasan Pendengar Program Dialog Interaktif Halo Kaltim Radio Republik Indonesia Samarinda.

\section{DAFTAR PUSTAKA}

Gani, Irwan dan Siti Amalia. 2015. Alat Analisis Data: Aplikasi Statistik Untuk Penelitian Bidang Ekonomi dan Sosial. Yogyakarta: Andi Offset.

Ghozali, Imam. 2011. Aplikasi Analisis Multivariate Dengan Program SPSS. Semarang: Badan Penerbit Universitas Diponegoro.

Kotler, Philip dan Gerry Armstrong. 2014. Marketing: An Introduction. England: Pearson Education Limited.

Kotler, Philip dan Kevin Lane Keller. 2012. Marketing Management. New Jersey: Pearson Education, Inc.

Sugiyono. 2013. Metode Penelitian Kuantitatif, Kualitatif dan R\&D. Bandung: Alfabeta. 